\title{
Verifikasi Metode Uji COD secara Spektrofotometri UV-Vis untuk Low Concentration dan High Concentration
}

\author{
Iqbal Ramadhan ${ }^{\text {a,*, }}$, Yulirohyami ${ }^{\text {a,** }}$, Rahmi Ahdiaty ${ }^{\text {b }}$ \\ ${ }^{a}$ Program Studi DIII Analisis Kimia, Jurusan Kimia, Fakultas Matematika dan Ilmu Pengetahuan Alam, Universitas Islam Indonesia \\ ${ }^{\mathrm{b}}$ Dinas Lingkungan Hidup Kota Yogyakarta \\ *corresponding author : iqbalramadhan121299@gmail.com \\ ** corresponding author : rohyami@uii.ac.id \\ DOI : 10.20885/ijca.vol5.iss1 art6
}

\section{ARTIKEL INFO}

Diterima : 16 Desember 2021

Direvisi : 08 Februari 2022

Diterbitkan : 01 Maret 2022

Kata kunci : COD low-high

concentration, verifikasi metode, MDL,LOQ, presisi, akurasi,

ketidakpastian pengukuran

\begin{abstract}
ABSTRAK
Telah dilakukan verifikasi metode uji chemical oxygen demand (COD) dengan metode spektrometri UV-Vis secara refluks tertutup. Verifikasi metode ini dilakukan untuk mengkonfirmasi metode SNI 6989.2:2019 untuk nilai COD low concentration dan high concentration. Parameter verifikasi metode meliputi penentuan lineritas, method detection limit, limit of quantification, presisi, dan akurasi. Berdasarkan hasil penelitian menunjukkan bahwa metode penentuan COD untuk low concentration dan high concentration memiliki lineritas yang telah memenuhi persyaratan keberterimaan dalam standar dengan koefisien korelasi masingmasing $-0,9985$ dan 0,9993 . Metode ini memiliki sensitivitas yang tinggi dengan nilai MDL pada low concentration dan high concentration masing-masing 2,05 dan $53,57 \mathrm{mg} / \mathrm{L}$ dan LOQ 6,53 dan $170,43 \mathrm{mg} / \mathrm{L}$. Nilai MDL untuk low concentration telah memenuhi persyaratan keberterimaan dengan nilai \% RSD 10,41\%, $\%$ Recovery sebesar 99,20\%, nilai signal to noise sebesar 9,60 dan nilai $10 \%$ spike sebesar 0,63 . Nilai MDL pada high concentration juga memenuhi persyaratan keberterimaan dengan nilai \% RSD $10,52 \%, \%$ Recovery $100,20 \%$, nilai signal to noise sebesar 9,50 dan nilai $10 \%$ spike sebesar 16,20. Pengujian COD pada low concentration dan high concentration memiliki presisi yang tinggi dengan \% RSD masing-masing 3,70 dan 4,34\% yang berada di bawah nilai CV Horwitz. Hasil uji varian dengan selang kepercayaan 95\% menunjukkan bahwa kedua metode ini memiliki presisi pengukuran yang tidak berbeda secara signifikan. Kedua metode ini juga memiliki akurasi yang tinggi dengan \% Recovery masing-masing 101,02 dan 101,98\%. Hasil uji rerata dengan selang kepercayaan 95\% juga menunjukkan bahwa kedua metode ini memiliki akurasi yang tidak berbeda secara signifikan.
\end{abstract}

ARTICLE INFO

Received : 16 December 2021

Revised :08 February 2022

Published : 01 March 2022

Keywords : COD low-high

concentration, verification method,

$M D L, L O Q$, precision, accuracy,

\section{ABSTRACT}

Determination of chemical oxygen demand using UV-Vis spectrometric with close reflux has been verified. The verification method is carried out to confirm the SNI 6989.2:2019 low and high concentration COD values. Method verification parameters include linearity, method detection limit, the limit of quantification, 
uncertainty

\section{PENDAHULUAN}

Chemical oxygen demand (COD) merupakan parameter utama dalam pengujian kualitas air. Nilai COD dapat digunakan sebagai rujukan dalam mengukur kualitas air atau beban cemaran air [1], [2]. Beban cemaran air tersebut berasal dari kandungan oksigen terlarut dalam air. Nilai COD sendiri menyatakan kebutuhan oksigen kimiawi sebagai miligram $\mathrm{O}_{2}$ yang digunakan untuk reaksi oksidasi zat-zat organik dalam 1 liter sampel air [3]. Nilai COD digunakan sebagai indeks terhadap pencemaran air yang dilakukan oleh zat-zat organik yang dapat dioksidasi melalui mikrobiologis, sehingga dampak yang ditimbulkan adalah berkurangnya oksigen terlarut dalam air. Oleh karena itu pengujian COD menjadi perhatian penting dalam pengujian kualitas air.

Metode uji COD berkembang mulai dari metode volumetri [4]-[8], spektrofotometri UV-Vis [3], [9]-[14], sensori [4], [5], [15], dan elektrokimia [16]. Metode standar yang digunakan dalam uji COD adalah metode refluks tertutup secara spektrofotometri UV-Vis yang mengacu pada SNI 6989.2:2019 [3]. Metode ini memiliki tingkat sensitifitasnya lebih tinggi dan waktu pengujian lebih singkat. Metode ini juga dapat berlaku untuk nilai COD pada rentang low concentration dan high concentration [3]. Metode refluks tertutup merupakan metode yang ramah lingkungan dengan meminimalkan jumlah sampel dan pereaksi [9][14]. Metode ini berlaku pada rentang low concentration dan high concentration. Oleh karena itu perlu dipelajari pengaruh low concentration dan high concentration terhadap lineritas, sensitivitas, presisi, dan akurasinya sebelum digunakan sebagai prosedur uji rutin di laboratorium. Metode SNI 6989.2:2019 pada rentang high concentration telah diverifikasi dan memberikan lineritas, sensitivitas, presisi, dan akurasi yang baik [14]. Namun demikian, metode ini belum diverifikasi pada dua rentang sehingga perlu dilakukan verifikasi pada low concentration dan high concentration.

Penelitian ini difokuskan pada verifikasi metode uji COD pada rentang low concentration dan high concentration. Verifikasi metode uji dilakukan untuk memastikan bahwa metode dapat digunakan sebagai pengujian rutin di laboratorium pada level low concentration dan high concentration. Penelitian ini juga dilakukan untuk mempelajari keberterimaan dan signifikansi dalam pengendalian mutu hasil pengujian yang meliputi lineritas, method detection limit, limit of quantification, presisi, dan akurasi. Penelitian ini juga digunakan untuk menganalisis faktor penyumbang estimasi ketidakpastian pengukuran pada pengujian low concentration dan high concentration. 


\section{METODE}

\subsection{Bahan}

Bahan yang digunakan meliputi air bebas organik, larutan standar COD $1.000 \mathrm{mg} / \mathrm{L}$ (certified reference material, CRM), asam sulfat (analytical grade), kalium dikromat (analytical grade), perak sulfat (analytical grade), dan merkuri sulfat (analytical grade).

\subsection{Pembuatan Digestion Solution}

Kalium dikromat yang telah dikering dalam oven $105^{\circ} \mathrm{C}$ selama 2 jam kemudian didinginkan dalam desikator. Sebanyak 1,022 g kalium dikromat ditimbang kemudian dimasukkan ke dalam gelas beaker $250 \mathrm{~mL}$ dan dilarutkan dengan $167 \mathrm{~mL} \mathrm{H}_{2} \mathrm{SO}_{4}$ pekat secara perlahan-lahan. Larutan didinginkan kemudian ditambah 33,3 gram $\mathrm{HgSO}_{4}$, diaduk hingga homogen. Larutan dipindahkan ke dalam labu ukur $1.000 \mathrm{~mL}$ kemudian ditera dan dihomogenkan.

\subsection{Pembuatan Deret Standar COD}

Sebanyak $5 \mathrm{~mL}$ larutan standar COD $1.000 \mathrm{mg} / \mathrm{L}$ dimasukkan ke dalam labu ukur $50 \mathrm{~mL}$ kemudian ditepatkan volumenya dengan akuades dan dihomogenkan. Deret standar low concentration dibuat dengan konsentrasi 10;30;50;70; dan $90 \mathrm{mg} / \mathrm{L}$ sedangkan deret standar high concentration dibuat dengan konsentrasi 100; 300; 500; 700; dan $900 \mathrm{mg} / \mathrm{L}$. masing-masing deret standar dipipet $2,5 \mathrm{~mL}$ dimasukkan ke dalam digestion vessel. Larutan ditambah dengan $1,5 \mathrm{~mL}$ digestion solution dan $3,5 \mathrm{~mL}$ asam sulfat pro-COD. Tabung dimasukkan ke dalam reaktor COD. Digesti dilakukan pada suhu $150^{\circ} \mathrm{C}$ selama 2 jam. Larutan yang telah didigesti didinginkan sampai suhu ruangan. Larutan deret standar COD diukur absorbansinya dengan spektrofotometer UV-Vis pada panjang gelombang $600 \mathrm{~nm}$ untuk low concentration dan $420 \mathrm{~nm}$ untuk high concentration.

\subsection{Penentuan Method Detection Limit (MDL)}

Penentuan MDL untuk low concentration menggunakan larutan standar COD $30 \mathrm{mg} / \mathrm{L}$ dan untuk high concentration menggunakan larutan standar COD $300 \mathrm{mg} / \mathrm{L}$. Masing-masing larutan standar dipipet 2,5 mL kemudian dimasukkan ke dalam digestion vessel, ditambah 1,5 digestion solution dan 3,5 $\mathrm{mL}$ asam sulfat pro-COD. Digesti dilakukan pada suhu $150^{\circ} \mathrm{C}$ selama $2 \mathrm{jam}$. Larutan yang telah didigesti didinginkan sampai suhu ruangan. Larutan standar COD diukur absorbansinya dengan spektrofotometer UV-Vis pada panjang gelombang $600 \mathrm{~nm}$ untuk low concentration dan $420 \mathrm{~nm}$ untuk high concentration.

\subsection{Penentuan Presisi}

Sebanyak 2,5 mL sampel dimasukkan ke dalam digestion vessel dengan 7 kali pengulangan dan ditambahkan $1,5 \mathrm{~mL}$ digestion solution dan $3,5 \mathrm{~mL}$ asam sulfat pro-COD. Digestion vessel dimasukkan ke dalam COD reaktor pada suhu $150^{\circ} \mathrm{C}$ selama 2 jam. Hasil digesti didinginkan hingga suhu ruang. Contoh diukur absorbansinya menggunakan spektrofotometer UV-Vis pada panjang gelombang $420 \mathrm{~nm}$.

\subsection{Penentuan Akurasi}

Larutan standar COD $10 \mathrm{mg} / \mathrm{L}$ dimasukkan ke dalam digestion vessel dengan 7 kali pengulangan dan ditambahkan $1,5 \mathrm{~mL}$ digestion solution dan $3,5 \mathrm{~mL}$ asam sulfat pro-COD. Digestion vessel dimasukkan kedalam COD reaktor pada suhu $150^{\circ} \mathrm{C}$ selama 2 jam. Hasil digesti didinginkan hingga suhu ruang. Larutan diukur absorbansinya menggunakan spektrofotometer UVVis pada panjang gelombang $420 \mathrm{~nm}$.

\subsection{Penentuan Ketidakpastian Pengukuran}

Ketidakpastian pengukuran ditentukan melalui tahapan 1) membuat skema kerja, 2) membuat diagram tulang ikan dari faktor-faktor yang memberikan kontribusi pada kesalahan pengukuran, 3) menentukan nilai ketidakpastian baku dari setiap sumber, 4) menentukan ketidakpastian gabungan dari ketidakpastian relatif, dan 5) menentukan ketidakpastian diperluas. 


\section{HASIL PENELITIAN}

\subsection{Penentuan Lineritas Larutan Standar COD}

Lineritas kurva kalibrasi larutan standar COD low concentration dan high concentration ditunjukkan pada Gambar 1. Gambar 1 menunjukkan bahwa larutan standar COD low concentration dan high concentration memiliki lineritas yang memenuhi syarat keberterimaan dalam standar SNI 6989.2:2019 [3]. Koefisien korelasi kurva kalibrasi larutan standar COD low concentration dan high concentration masing-masing adalah $-0,9985$ dan 0,9990, yang memenuhi persyaratan dalam SNI 6989.2:2019 [3]. Kurva kalibrasi memiliki lineritas yang baik dengan koefien korelasi $\geq 0,995$ dengan intersep lebih $\leq$ batas deteksi [9][11][12].

Gambar 1. (a) menunjukkan kurva kalibrasi larutan standar COD low concentration dari deret larutan standar 0, 10, 30, 50, 70, dan $90 \mathrm{mg} / \mathrm{L}$. Kurva kalibrasi larutan standar COD low concentration mengikuti persamaan $\mathrm{y}=-0,0024 \mathrm{x}+0,3203$. Persamaan tersebut memiliki intersep 0,3203 lebih kecil dari nilai batas deteksi, yaitu $2,05 \mathrm{mg} / \mathrm{L}$. Kurva kalibrasi larutan standar COD high concentration pada Gambar 1. (b) mengikuti persamaan regresi linear $\mathrm{y}=0,0004 \mathrm{x}-0,001$. Nilai intersep 0,001 lebih kecil dari batas deteksinya, yaitu 53,57 mg/L. Kedua deret larutan standar COD low concentration dan high concentration ini memiliki lineritas yang telah memenuhi persyaratan yang dipersyaratkan dalam SNI 6989.2:2019 [3]. Kurva kalibrasi low concentration dan high concentration memiliki lineritas yang baik [9], [12]-[14].

(a)

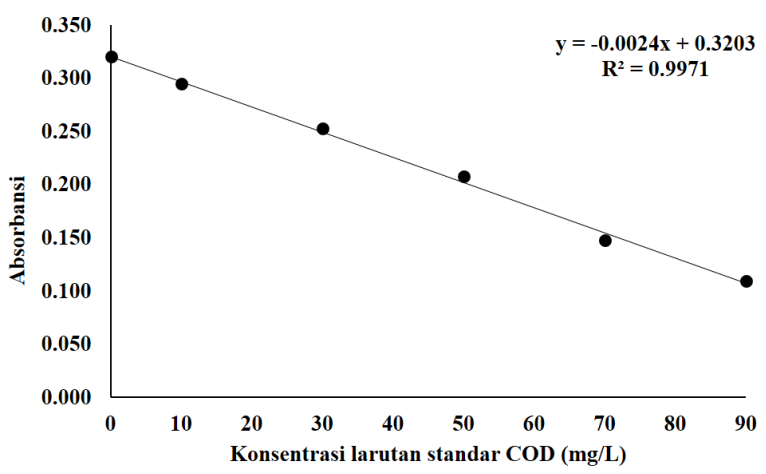

(b)

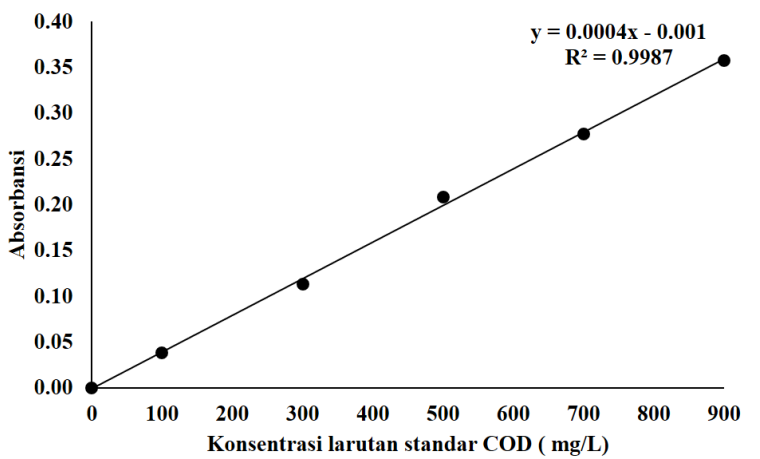

Gambar 1. Kurva kalibrasi larutan standar COD (a) low concentration (b) high concentration
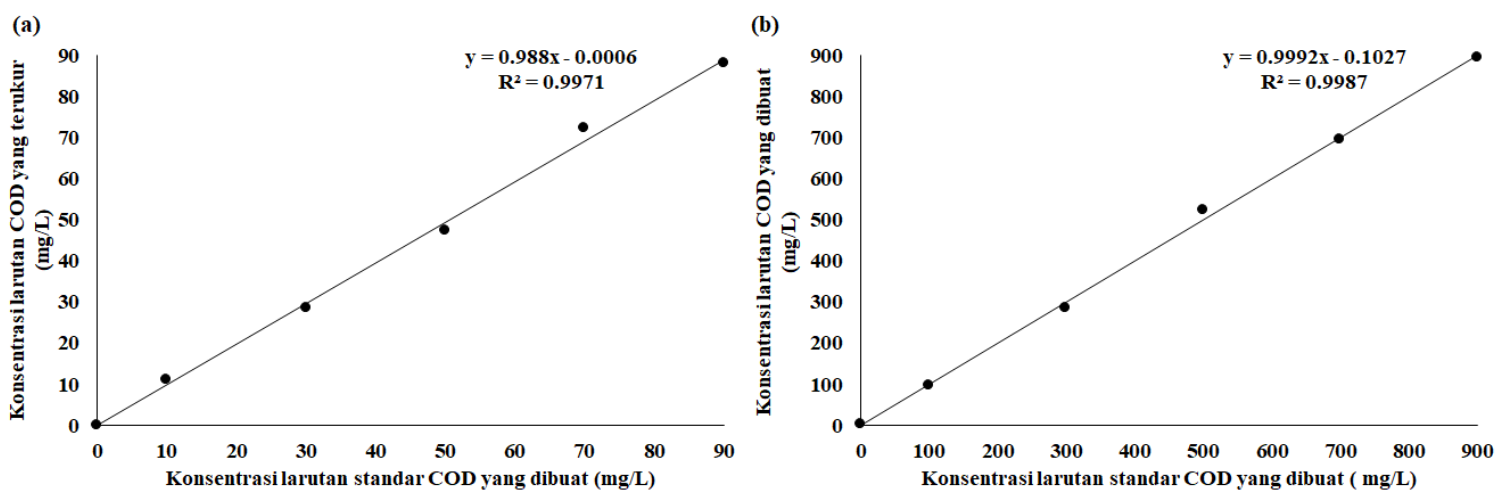

Gambar 2. Konsentrasi larutan standar COD yang terukur (a) low concentration (b) high concentration

Berdasarkan hasil pengukuran deret larutan standar COD, hasil pengukuran konsentrasi yang dibuat memiliki korelasi yang baik dengan konsentrasi larutan standar COD yang terukur [9][11][12]. Larutan standar COD dibuat dari CRM pada low concentration dan high concentration. Gambar 2 menunjukkan kurva korelasi antara konsentrasi yang dibuat dengan konsentrasi yang terukur dengan koefisien korelasi -0,9985 untuk deret standar low concentration dan 0,9993 untuk deret standar high concentration. Gambar 2 (a) menunjukkan bahwa larutan standar COD low concentration menunjukkan model regresi linear yang mengikuti persamaan y = 
$0,998 \mathrm{x}-0,0006$. Model regresi untuk larutan standar COD high concentration ditunjukkan pada Gambar 2 (b) dengan persamaan $\mathrm{y}=0,9992 \mathrm{x}-0,1027$.

\subsection{Penentuan Method Detection Limit (MDL) dan Limit of Quantification (LOQ)}

Pengujian COD dengan deret standar COD low concentration dan high concentration memiliki nilai MDL yang memenuhi persyaratan keberterimaan dalam standar. Nilai MDL menunjukkan konsentrasi COD yang dapat ditentukan sesuai tahapan metode pengujian secara menyeluruh sehingga menghasilkan sinyal dengan kemungkinan $99 \%$, yang berbeda dengan blanko. Nilai MDL juga menunjukkan kemampuan laboratorium untuk mengukur COD dengan metode ini dengan konsentrasi minimum sehingga dapat menghindari pengujian yang tidak terbaca atau tidak terdeteksi.

TABEL I. MDL dan LOQ untuk COD low concentration dan high concentration

\begin{tabular}{lcc}
\hline Parameter & COD low concentration & COD high concentration \\
\hline Rerata pengukuran (mg/L) & 6,275 & 161,975 \\
\% Recovery & 99,20 & 100,20 \\
Standar deviasi (SD) & 0,6534 & 17,0429 \\
\%RSD & 10,41 & 10,52 \\
MDL (3,143 x SD), mg/L & 2,05 & 53,57 \\
LOQ (10 x SD) & 6,53 & 170,43 \\
Signal/Noise (S/N) & 9,60 & 9,50 \\
$10 \%$ spike & 0,63 & 16,20 \\
\hline
\end{tabular}

Tabel 1 menunjukkan bahwa nilai MDL pada low concentration dan high concentration masing-masing 2,05 dan 53,57 mg/L dengan nilai LOQ 6,53 dan 170,43. Nilai MDL untuk low concentration memenuhi syarat keberterimaan dengan nilai \%RSD tidak lebih dari $2 / 3 \mathrm{CV}$ Horwitz, dengan nilai uji perolehan kembali atau recovery test $\% \mathrm{R}=100 \% \pm 50 \%$, nilai signal to noise rasio berada pada rentang 2,5-10, dan nilai 10\% spike $<\mathrm{MDL}<$ spike. Tabel I menunjukkan nilai MDL telah memenuhi semua syarat kebeterimaan dengan nilai \% RSD 10,41\%, \% Recovery sebesar 99,20\%, nilai signal to noise sebesar 9,60 dan nilai 10\% spike sebesar 0,63.

Tabel 1 juga menunjukkan bahwa nilai MDL pengujian COD dengan larutan standar high concentration telah memenuhi persyaratan keberterimaan data. Nilai MDL telah memenuhi semua syarat kebeterimaan dengan nilai \% RSD 10,52\%, \% Recovery sebesar 100,20\%, nilai signal to noise sebesar 9,50 dan nilai 10\% spike sebesar 16,20. Berdasarkan hasil penelitian menunjukkan bahwa pengujian COD pada low concentration dan high concentration memiliki sensitivitas yang baik [9][14].

\subsection{Penentuan Presisi}

Tabel 2 menunjukkan hasil penentuan presisi pengujian COD dengan menggunakan larutan standar COD low concentration dan high concentration. Tabel 2 menunjukkan bahwa pengujian COD low concentration dan high concentration memiliki \% RSD masing-masing 3,70 dan 4,34 \%. Hasil pengujian menunjukkan bahwa kedua metode pengujian ini memenuhi persyaratan keberterimaan dalam SNI 6989.2:2019 sebesar $\approx 5,36 \%$ [3]. Metode uji COD dengan menggunakan larutan standar COD low concentration dan high concentration memiliki nilai \%RSD di bawah nilai CV Horwitz, sehingga kedua metode memiliki presisi yang tinggi [9][14].

Hasil uji varian untuk pengukuran COD low concentration dan high concentration dengan $\mathrm{df}$ $=6$ dan selang kepercayaan $95 \%$ diperoleh $\mathrm{F}$ hitung 0,0040 yang nilainya lebih kecil dari $\mathrm{F}$ tabel 0,1718 . Berdasarkan hasil uji varian ini menunjukkan bahwa kedua metode ini memiliki variansi pengukuran yang sama, baik metode pengukuran COD low concentration maupun high concentration. Kedua metode ini memiliki presisi pengukuran yang tidak berbeda secara signifikan. 
TABEL II. Penentuan presisi COD low concentration dan high concentration

\begin{tabular}{lcc}
\hline \multirow{2}{*}{ Replikasi } & \multicolumn{2}{c}{ Konsentarasi COD $(\mathrm{mg} / \mathrm{L})$} \\
\cline { 2 - 3 } & Low concentration & High concentration \\
\hline 1 & 8,10 & 102,99 \\
2 & 8,48 & 108,92 \\
3 & 7,66 & 112,25 \\
4 & 7,73 & 101,88 \\
5 & 8,13 & 111,05 \\
6 & 8,25 & 113,00 \\
7 & 8,31 & 113,11 \\
\hline Rerata & 8,09 & 109,03 \\
Standar deviasi (SD) & 0,30 & 4,73 \\
\%RSD & 3,70 & 4,34 \\
CV Horwirtz & 11,68 & 7,90 \\
$2 / 3$ CV Horwitz & 7,79 & 5,26 \\
\hline
\end{tabular}

TABEL III. Penentuan akurasi COD low concentration dan high concentration

\begin{tabular}{lcc}
\hline \multirow{2}{*}{ Replikasi } & \multicolumn{2}{c}{$\%$ Recovery } \\
\cline { 2 - 3 } & Low concentration & High concentration \\
\hline 1 & 95,17 & 101,68 \\
2 & 107,71 & 103,40 \\
3 & 101,87 & 103,63 \\
4 & 97,04 & 102,07 \\
5 & 112,38 & 98,47 \\
6 & 96,76 & 102,13 \\
7 & 96,18 & 102,49 \\
\hline Rerata & 101,02 & 101,98 \\
\hline
\end{tabular}

\subsection{Penentuan Akurasi}

Tabel 3 menunjukkan bahwa \% Recovery pada penentuan COD dengan larutan standar COD low concentration dan high concentration masing-masing 101,02 dan 101,98\%. Akurasi tersebut telah memenuhi persyaratan keberterimaan yang ditetapkan dalam SNI 6989.2:2019 dengan rentang $85-110 \%$ [3]. Kedua metode tersebut memiliki akurasi yang tinggi [9][14]. Hasil uji rerata untuk pengukuran COD low concentration dan high concentration dengan selang kepercayaan $95 \%$ diperoleh $\mathrm{t}$ hitung 0,3583 yang nilainya lebih kecil dari $\mathrm{t}$ tabel 0,3716 . Berdasarkan hasil uji rerata ini menunjukkan bahwa metode penentuan COD low concentration dan high concentration menunjukkan akurasi pengujian yang tidak berbeda secara signifikan.

\subsection{Penentuan Estimasi Ketidakpastian Pengukuran}

Ketidakpastian pengukuran pada penentuan COD dengan larutan standar low concentration dan high concentration dilakukan melalui tahapan 1) membuat skema kerja, 2) membuat diagram tulang ikan dari faktor-faktor yang memberikan kontribusi pada kesalahan pengukuran, 3) menentukan nilai ketidakpastian baku dari setiap sumber, 4) menentukan ketidakpastian gabungan dari ketidakpastian relatif, dan 5) menentukan ketidakpastian diperluas. 
(a)

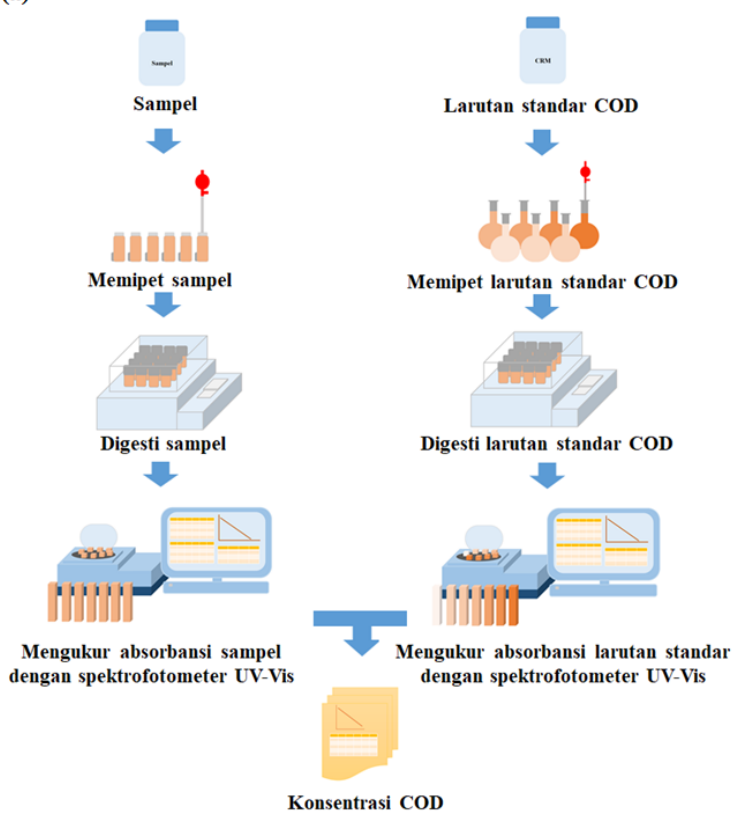

(b)

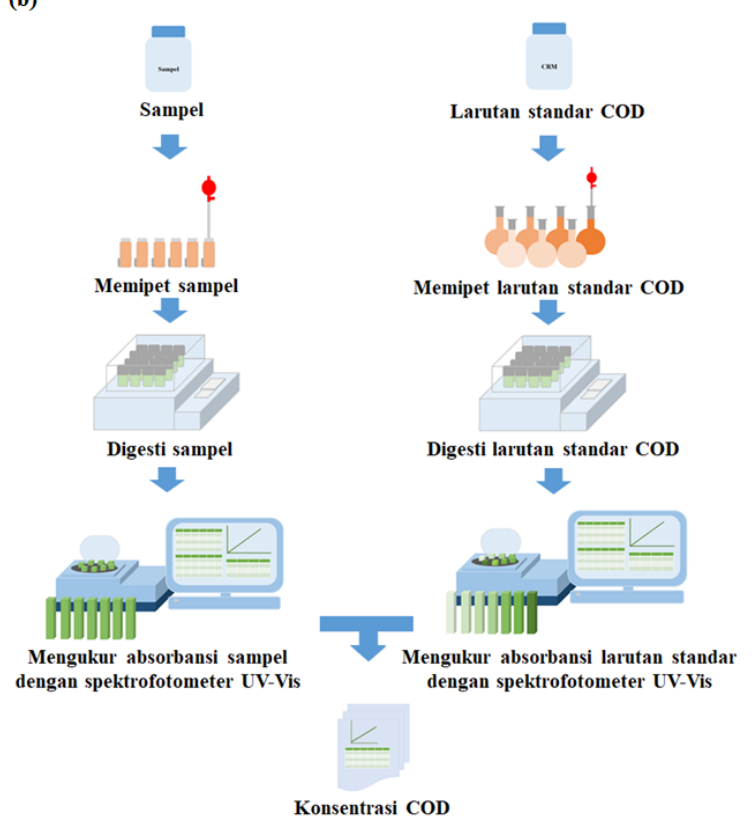

Gambar 3. Penentuan COD dengan larutan standar (a) low concentration (b) high concentration

Skema kerja penentuan COD ditunjukkan pada Gambar 3. Gambar 3 (a) dan 3 (b) menunjukkan skema kerja penentuan COD pada low concentration dan high concentration. Penentuan COD dilaksanakan melalui tahap memipet sampel dan larutan standar, mendigesti sampel dan larutan standar, serta mengukur absorbansi sampel dan larutan standar. Berdasarkan skema kerja pada Gambar 3 dapat dibuat diagram tulang ikan penentuan COD yang ditunjukkan pada Gambar 4. Gambar 4 menunjukkan diagram tulang ikan penentuan COD secara spektrofotometri UV-Vis. Berdasarkan skema kerja pada Gambar 3. Dapat diidentifikasi sumbersumber yang memberikan kontribusi pada kesalahan pada penentuan COD yang meliputi memipet sampel [9], konsentrasi COD [9], pengulangan [9][11], dan mendigesti sampel dengan reaktor COD. Ketidakpastian pengukuran dari memipet sampel berasal dari kalibrasi pipet ukur $5 \mathrm{~mL}$ dan faktor muai temperatur. Ketidakpastian konsentrasi COD berasal dari kurva kalibrasi larutan standar COD. Ketidakpastian pengulangan berasal dari presisi sedangkan ketidakpastian pengukuran dari reaktor COD berasal dari kalibrasi alat.

Tabel 4 menunjukkan sumber ketidakpastian pengukuran pada penentuan COD secara refluks tertutup dengan metode spektrofotometri UV-Vis, nilai ketidakpastian baku, ketidakpastian relative, ketidakpastian gabungan, dan ketidakpastian diperluas dengan menggunakan faktor kapasitas dengan selang kepercayaan 95\%.

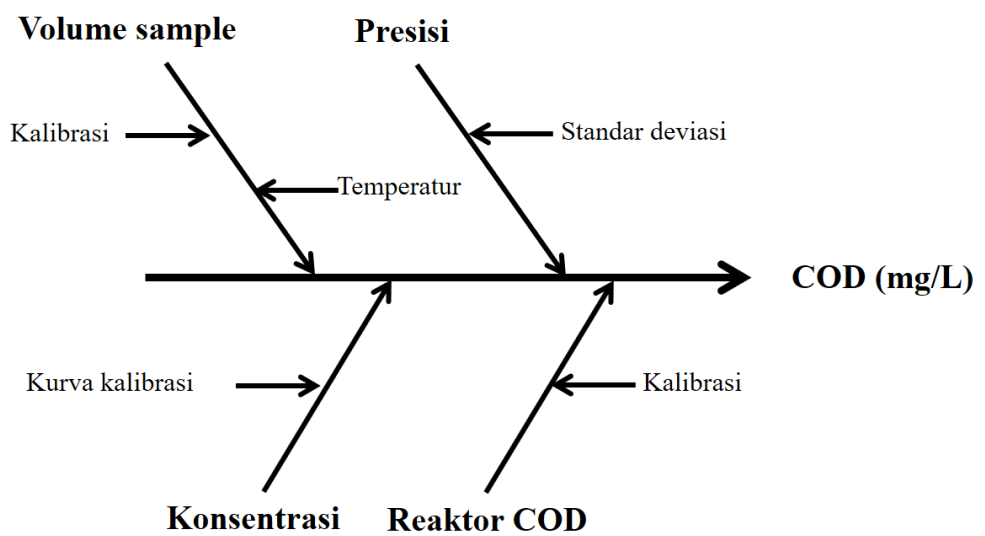

Gambar 4. Diagram tulang ikan penentuan COD secara refluks tertutup dengan spektrofotometri UV-Vis 
TABEL IV. Penentuan ketidakpastian pengukuran low concentration dan high concentration

\begin{tabular}{lccccccc}
\hline \multirow{2}{*}{ Sumber } & \multirow{2}{*}{ Unit } & \multicolumn{3}{c}{ Low concentration } & \multicolumn{3}{c}{ High concentration } \\
\cline { 3 - 8 } & & Value $(\mathrm{x})$ & $\left(\mu_{(\mathrm{x})}\right)$ & $\left(\mu_{(\mathrm{x})}\right) / \mathrm{x}$ & Value $(\mathrm{x})$ & $\left(\mu_{(\mathrm{x})}\right)$ & $\left(\mu_{(\mathrm{x})}\right) / \mathrm{x}$ \\
\hline Volume sampel & $\mathrm{mL}$ & 2,5 & 0,0017 & 0,0007 & 2,5 & 0,0017 & 0,0007 \\
Konsentrasi & $\mathrm{mg} / \mathrm{L}$ & 8,094 & $-1,8244$ & $-0,2254$ & 109,028 & 13,7394 & 0,1260 \\
Presisi & $\mathrm{mg} / \mathrm{L}$ & 8,094 & 3,6953 & 0,0457 & 109,028 & 4,3416 & 0,0398 \\
Reaktor COD & ${ }^{\circ} \mathrm{C}$ & 150 & 1,1000 & 0,0073 & 150 & 1,1000 & 0,0073 \\
\hline Ketidakpastian gabungan & $\mathrm{mg} / \mathrm{L}$ & \multicolumn{3}{c}{0,5092} & & 0,1324 \\
Ketidakpastian diperluas & $\mathrm{mg} / \mathrm{L}$ & \multicolumn{3}{c}{1,02} & & & 0,26 \\
\hline
\end{tabular}

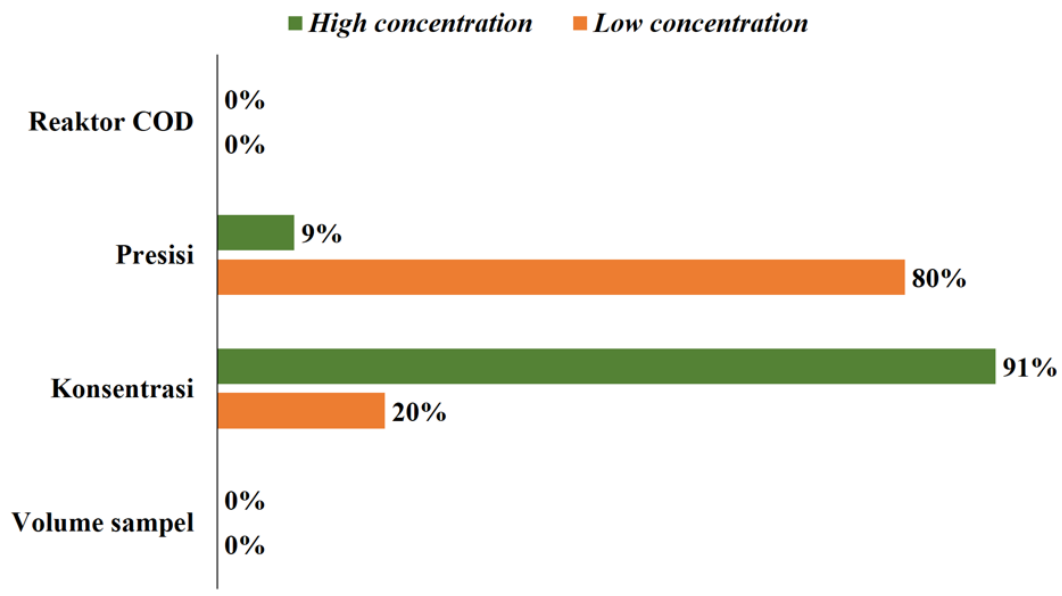

Gambar 5. Penyumbang ketidakpastian pengukuran pada penentuan COD secara refluks tertutup dengan spektrofotometri UV-Vis

Hasil penentuan ketidakpastian pengukuran ini digunakan untuk melaporkan hasil uji yang menyatakan batas keberterimaan data pengujian. Berdasarkan hasil perhitungan pada rerata hasil pada Tabel 2 dan penentuan estimasi ketidakpastian pengukuran pada Tabel 4 dapat dinyatakan nilai COD untuk low concentration dan high concentration adalah 8,09 $\pm 1,02$ dan 109,03 $\pm 0,26$ $\mathrm{mg} / \mathrm{L}$. Nilai ketidakpastian pengukuran pada pengukuran COD low concentration lebih tinggi dibandingkan pada pengukuran high concentration.

Berdasarkan hasil perhitungan dapat ditentukan nilai penyumbang ketidakpastian pengukuran terbesar pada penentuan COD secara refluks tertutup dengan spektrofotometri UV-Vis untuk low concentration berasal dari presisi, sedangkan pada high concentration berasal dari kurva kalibrasi. Pengujian COD pada low concentration membutuhkan kecermatan pengukuran mulai dari pengambilan contoh uji dan proses digesti sampel pada setiap replikasi pengujian. Keterulangan pengujian COD pada konsentrasi yang rendah memberikan kontribusi yang signifikan terhadap keterulangan nilai pengukuran [9]. Namun demikian, faktor keterulangan ini masih berada dalam batas yang dapat diterima sepanjang rentang keberterimaan ini dilaporkan dalam data hasil uji. Hal ini dapat dilihat dari presisi pengujian yang tinggi dan memenuhi persyaratan keberterimaan dalam standar [9].

Pengujian COD pada low concentration didasarkan pada pengukuran krom(VI) dari sisa kalium dikromat yang digunakan pada reaksi oksidasi senyawa organik. Berbeda dengan pengujian COD pada high concentration yang didasarkan pada pengukuran krom(III) dari reduksi kalium dikromat oleh senyawa organik dalam sampel uji. Nilai COD yang rendah menunjukkan bahwa kandungan senyawa organik dalam sampel yang lebih rendah sehingga kurang memberikan sensitivitas pada pembacaan absorbansi pada intensitas warna yang diberikan. Namun demikian, pengaruh keterulangan pada low concentration ini masih berada dalam batas kemampuan alat untuk mendeteksi sampel. Hal ini ditunjukkan dari data nilai MDL dan LOQ pada low 
concentration masing-masing 2,05 dan $6,53 \mathrm{mg} / \mathrm{L}$. Pengukuran COD pada sampel yang memiliki nilai COD 8,09 $\pm 1,02 \mathrm{mg} / \mathrm{L}$ masih dapat dideteksi dan dikuantifikasikan dengan baik.

Kecermatan pengukuran juga memberikan kontribusi penyumbang ketidakpastian pengukuran pada kurva kalibrasi. Pengujian COD pada high concentration memiliki faktor penyumbang ketidakpastian pengukuran terbesar berasal dari kurva kalibrasi. Penyiapan deret standar dipengaruhi oleh kecermatan dalam memipet sejumlah tertentu larutan standar dan kecermatan dalam menepatkan volume larutan dalam labu ukur. Kesalahan dalam pembacaan meniskus untuk larutan yang memiliki konsentrasi tinggi akan memberikan kontribusi kesalahan yang lebih tinggi dibandingkan pada konsentrasi rendah.

\section{KESIMPULAN}

Berdasarkan hasil penelitian menunjukkan bahwa metode penentuan COD untuk low concentration dan high concentration memiliki lineritas yang telah memenuhi persyaratan keberterimaan dalam standar dengan koefisien korelasi masing-masing -0,9985 dan 0,9993. Metode ini memiliki sensitivitas yang baik dengan nilai MDL pada low concentration dan high concentration masing-masing 2,05 dan 53,57 mg/L serta nilai LOQ 6,53 dan 170,43 mg/L. Nilai MDL untuk low concentration telah memenuhi persyaratan kebeterimaan dengan nilai \% RSD 10,41\%, \% Recovery sebesar 99,20\%, nilai signal to noise sebesar 9,60 dan nilai 10\% spike sebesar 0,63 . Nilai MDL pada high concentration juga memenuhi persyaratan keberterimaan dengan nilai \% RSD 10,52\%, \% Recovery 100,20 \%, nilai signal to noise sebesar 9,50 dan nilai $10 \%$ spike sebesar 16,20. Pengujian COD pada low concentration dan high concentration memiliki presisi yang tinggi dengan \% RSD masing-masing 3,70 dan 4,34 \% yang berada di bawah nilai CV Horwitz. Hasil uji varian dengan selang kepercayaan 95\% menunjukkan bahwa kedua metode ini memiliki presisi pengukuran yang tidak berbeda secara signifikan. Kedua metode ini juga memiliki akurasi yang tinggi dengan \% Recovery masing-masing 101,02 dan 101,98\%. Hasil uji rerata dengan selang kepercayaan $95 \%$ juga menunjukkan bahwa kedua metode ini memiliki akurasi yang tidak berbeda secara signifikan.

\section{Daftar Pustaka}

[1] T. E. Aniyikaiye, T. Oluseyi, J. O. Odiyo, and J. N. Edokpayi, 'Physico-chemical analysis of wastewater discharge from selected paint industries in Lagos, Nigeria', Int. J. Environ. Res. Public Health, vol. 16, no. 7, 2019.

[2] M. Tamyiz, 'Perbandingan Rasio BOD/COD Pada Area Tambak Di Hulu Dan Hilir Terhadap Biodegradabilitas Bahan Organik', J. Res. Technol., vol. 1, no. 1, pp. 9-15, 2015.

[3] SNI.6989.2:2019, "Analisa COD Refluks Tertutup secara Spektrofotometri", 2019.

[4] J. Ma, 'Determination of chemical oxygen demand in aqueous samples with non-electrochemical methods', Trends Environ. Anal. Chem., vol. 14, no. April, pp. 37-43, 2017.

[5] N. Yao, J. Wang, and Y. Zhou, 'Rapid determination of the chemical oxygen demand of water using a thermal biosensor', Sensors (Switzerland), vol. 14, no. 6, pp. 9949-9960, 2014.

[6] J. Zhang et al., 'Wastewater COD characterization: RBCOD and SBCOD characterization analysis methods', Sci. Rep., vol. 11, no. 1, 2021.

[7] A. Gnanavelu, T. S. Shanmuganathan, V. Deepesh, and S. Suresh, 'Validation of a Modified Procedure for the determination of Chemical Oxygen Demand using standard dichromate method in industrial wastewater samples with high calcium chloride content', Indian J. Sci. Technol., vol. 14, no. 29, pp. 2391-2399, 2021.

[8] S. Zhang, W. Chen, Y. Liu, P. Luo, and H. Gu, 'A Modified Method for the Accurate Determination of Chemical Oxygen Demand (COD) in High Chloride Oilfield Wastewater', Open J. Yangtze Oil Gas, vol. 03, no. 04, pp. 263-277, 2018.

[9] Y. Rohyami, T. Aprianto, and Marjono, 'Validation Method on Determination of Chemical Oxygen Demand Using Indirect UV-Vis Spectrometry', Adv. Mater. Res., vol. 1162, pp. 101-108, 2021.

[10] J. Li, Y. Tong, L. Guan, S. Wu, and D. Li, 'A turbidity compensation method for COD measurements 
by UV-vis spectroscopy, Optik (Stuttg)., vol. 186, no. April, pp. 129-136, 2019.

[11] S. Dimitrova et al., 'Comparison of spectrophotometric methods using cuvette tests and national standard methods for analysis of wastewater samples', Int. J. Water Resour. Environ. Eng., vol. 5, no. 8, pp. 482-488, 2013.

[12] C. Wang, W. Li, and M. Huang, 'High precision wide range online chemical oxygen demand measurement method based on ultraviolet absorption spectroscopy and full-spectrum data analysis', Sensors Actuators, B Chem., vol. 300, no. August, p. 126943, 2019.

[13] N. Kishimoto and M. Okumura, 'Feasibility of mercury-free chemical oxygen demand (COD) test with excessive addition of silver sulfate', J. Water Environ. Technol., vol. 16, no. 6, pp. 221-232, 2018.

[14] U. Hasanah, A. Heri Mulyati, D. Widiastuti, S. Warnasih, Y. Syahputri, and T. Panji, 'Development of Cod (Chemical Oxygen Demand) Analysis Method in Waste Water Using Uv-Vis Spectrophotometer', J. Sci. Innovare, vol. 03, no. 02, pp. 35-38, 2020.

[15] G. Le, H. Yang, and X. Yu, 'Improved UV/O3 method for measuring the chemical oxygen demand', Water Sci. Technol., vol. 77, no. 5, pp. 1271-1279, 2018.

[16] Y. Ge et al., 'Electrochemical determination of chemical oxygen demand using Ti/TiO2 electrode', Int. J. Electrochem. Sci., vol. 11, no. 12, pp. 9812-9821, 2016.

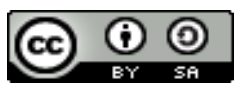

Jurnal IJCA is licensed under aÂ Creative Commons Attribution ShareAlike 4.0 